DOI: 10.47745/ERJOG.2020.02.05

\title{
JUHÁSZ IMRE
}

\section{Fiume és a nemzetiségi egyenjogúság tárgyában hozott 1868. évi XLIV. törvénycikk}

\section{Fiume and Act XLIV of 1868 on the Equal Rights of Minorities}

\begin{abstract}
Fiume (current official name: Rijeka) became part of Hungary in 1779 as a "corpus separatum". At the time of the so-called provision, after 1870, the legal system of the port city developed in a special way. Although the Hungarian government took over the administration of the city again, this did not mean the automatic reception and application of the entire Hungarian legal system. Some Hungarian laws were not later enacted in Fiume. The article prepared on the basis of the conference lecture in Cluj-Napoca (Sapientia Hungarian University of Transylvania) intends to review the issues of legal interpretation of the applicability of Act XLIV of 1868 on National Equality by using descriptive method, taking into account legal history and legal theory aspects.
\end{abstract}

Keywords: The city and port of Fiume (Rijeka), corpus separatum, temporary status and legal order, law enforcement, official language use.

Összefoglaló: Fiume 1779-ben került Magyarországhoz, mint „corpus separatum”. Az ún. provizórium idején 1870 után a kikötőváros jogrendszere sajátosan alakult. Bár újra a magyar kormány vette át a város igazgatását, ez nem jelentette a teljes magyar jogrendszer automatikus recepcióját és alkalmazását. A magyar törvények egy részét később sem léptették hatályba Fiuméban. Az Erdélyi Magyar Tudományegyetem szervezésében Kolozsváron tartott konferencia-előadás alapján készült írás a nemzetiségi egyenjogúság tárgyában hozott 1868. évi XLIV. törvénycikk fiumei alkalmazhatóságának jogértelmezési kérdéseit kivánja áttekinteni leiró módszerrel, a jogtörténeti, jogelméleti szempontokat figyelembe véve.

Kulcsszavak: Fiume városa és kikötője, corpus separatum, provizórium, jogalkalmazás, hivatalos nyelvhasználat.

\section{Bevezetés}

Fiume városa és kikötője a magyar történelemtudásunk mostohagyermeke. Fehér folt. Általában és különösen is.

Általánosságban talán annyit tud - ha létezik ilyen - az „átlag magyar”, hogy e város egykor Magyarország legnagyobb kikötője volt, de olaszosan hangzó nevén túl kevés konkrétumot tud felidézni. Talán még addig is eljut, hogy a város a mai Rijekával azonos, amely viszont jelenleg Horvátországhoz tartozik. És itt: függöny! 
Ami a különös világát illeti, adott néhány emlékfoszlány az idősebb nemzedékeknél, akik még hallhatták dédapáink I. világháborús dalait, és kissrácként elmerengtek arról, hogy milyen is lehetett, amikor a „fiumei kikötőben kikötött egy gözhajó...” Esetleg gyarapítja az emlékezet világát a közelmúlt isztriai nyaralása közben átutazóban készült néhány friss fotó a kikötő bakjairól, amelyek titokzatos magyar feliratokat őriznek öntöttvasba merevedve.

De különös e város jogtörténeti értelemben is. Szemben Magyarország XIX. század utolsó harmadában rohamosan egységesülő modern polgári jogrendszerével, mindvégig megtartotta unikális jellegét. Jogászi szemmel egészen elképesztő változatosságban hatályosultak a városban és nem egészen $20 \mathrm{~km}^{2}$-es kerületében a magyar, osztrák és helyi jogszabályok. Erről az időbeli és térbeli sokszínűségről és annak értelmezéséről lesz szó jelen cikkben, természetesen fókuszba helyezve a nemzetiségi egyenjogúság tárgyában hozott 1868. évi XLIV. törvénycikket (továbbiakban: teljes név, vagy nemzetiségi törvény), illetve annak fiumei státusát.

Írásomban arra is kitérnék - a vázlatos történelmi visszapillantást sem mellőzve -, hogy mi is volt Fiume státusa és szerepe a Magyar Királyságban. ${ }^{1}$

\section{Fiume történelme dióhéjban}

Anélkül, hogy részleteznénk több mint két és fél évezred várostörténetét, a kezdetekről talán annyit érdemes megjegyezni, hogy a mai Fiume területén az ókorban már város állt, ezen ős-Fiume illír eredetű vagy görög gyarmatosítók által alapított (Kr. e. VI. században) település lehetett. A terület rómaiak általi birtokbavétele csak a Kr. e. 30-as években stabilizálódott. Ezt jelezte Illíria provincia, majd Kr. u. 9-ben Pannónia és Dalmácia provinciák létrehozása. Ezután longobárdok, hunok, keleti gótok, avarok következtek. Nagy Károly idején komoly harcok színhelye az Eneo folyó (később olaszul: Fiumara, magyarul: Recsina, horvátul: Rječina/ Rečina) torkolatvidéke. Nagy Károly a keleti határokon őrgrófságokat állított fel (Friaul, Krajnai őrgrófság, illetve „Vindischmark”, amely magában foglalta Isztriát, a későbbi Görzöt, Triesztet és Krajna legnagyobb részét, illetve Fiumét. ${ }^{2}$ Bizánc is megpróbálta kiterjeszteni hatalmát a városra és környékére, ami azonban nem tartott sokáig és nem gátolta meg a Nagy Károly nevéhez füződő és hoszszú időre kiható intézkedések megvalósulását. Ezen intézkedések abban csúcsosodtak ki, hogy a várost és környékét hủbérbe kapta az aquileai patriarcha (Polai Püspökség). Ezután pedig nemesi családok birtoka volt a város. ${ }^{3}$

1 Az előadásra való felkészülésnél és jelen szerkesztett cikk megírásánál felhasználtam a Heraldika Kiadónál Fiume - egy közép-európai város és kikötő a hatalmi érdekek metszéspontjában címmel hamarosan megjelenő monográfiámat. Az érintett részeket külön nem tüntettem fel a hivatkozásoknál.

2 LÁzÁr Gyula: Fiume, a magyar korona gyöngye, Franklin-Társulat, Budapest, 1881, 59.

3 Fiumara (Recsina) folyó ekkor már másodszor válik határfolyóvá (elsőként: Bizánc idején). Így pl. III. Béla és IV. Béla magyar királyok Frangepánoknak címzett adományainak - azaz a Magyar Királyságnak (és benne a Gvozd-hegységtől délre elterülő Horvátországnak) - határát is jelezte. IV. Béla említette Fiumét e nevén először egy 1260-ban kelt oklevelében. 
Az utolsó család (Walsee-korszak) uralma 1465-ig (más forrás szerint 1471-ig4) tartott, mert Walsee Farkas styriai (Stájerország) helytartó Fiumét Habsburg III. Frigyes német-római császárnak engedte át azzal, hogy összes birtokai örököséül a császárt jelölte meg. Ezzel megszilárdította a következő több száz éves Habsburg-befolyást Fiume és kerülete felett.

1526-ban kidolgozták a városi autonómia dokumentumát, amelyet 1530-ban I. Ferdinánd megerősített. E statútum szerint Fiume lényegében törvényalkotásra is feljogosított városállammá vált, ${ }^{5}$ és használhatta a „res publica” címet. Lipót császár 1659-ben címerhasználatot engedélyezett. A címer átvészelte a történelem viharait, és a központi címerállatának, a kétfejű sasnak bal lába alól ma is víz ömlik a tengerbe kiapadhatatlanul. ${ }^{\circ}$ VI. Károly császár alatt Fiume ténylegesen is szabad kikötővé vált, miközben, mint külön tartományi státussal bíró közigazgatási egység, elfogadta a Pragmatica Sanctiót, amely prolongálta a Habsburg-fennhatóságot.

1775-ben a városba látogató trónörökös - a későbbi II. József - úgy vélte, hogy Fiume csak akkor fejlődhet, ha hátországa a Magyar Királyság lesz. Elképzelése egybeesett a városi tanács terveivel, amely kifejezetten kérte az impériumváltást az uralkodótól, Mária Teréziától, mivel ezen intézkedéstől a kikötő fejlesztését és a kereskedelmi forgalom bővülését, illetve a közeli Trieszttel szembeni másodhegedűs szereptől való szabadulást várták.7

Mária Terézia 1776 februárjában a magyar Szent Korona horvát királyságába kebelezte be a várost és kikötőjét, úgy, hogy a város felügyeletét és kormányzását a magyar udvari kancelláriára bízta. A részletek kidolgozása során hamar egyértelművé vált, hogy a sok vitát kiváltó kettős hatalmi megoldás - amelyet a fiumei városi tanács sem támogatott - nem bizonyult életképesnek, és így végül 1779. április 23-án Fiumét mint corpus separatumot „a kereskedelem és az ipar fölvirágoztatása érdekében saját akaratából” a Magyar Királysághoz csatolta a királynő, azzal, hogy azt közvetlenül (Horvátország közbeiktatása nélkül) igazgassa a magyar állam. A vonatkozó felséghatározat szerint: „Magyarország és a hozzá tartozó országok közjavára előirányzott intézkedései mellett a magyar kereskedelemről is gondoskodni akarván, azon tengermelléket, mely rövid ideig osztráknak neveztetett, de ősi joggal Magyarországhoz tartozott, ahhoz visszakapcsolja, azonfelül beleegyezik, hogy Fiume városa kerületével együtt ezentúl úgy tekintessék és kezeltessék, mint Magyarország szent koronájához csatolt külön test, s a buccari kerülettel, mely elejétöl fogva Horvátországhoz tartozott, össze ne zavartassék."

Most nincs lehetőségünk e felséghatározat mélyebb elemzésére, pl. a tekintetben, hogy az impériumváltást Magyarországhoz való visszacsatolásnak tekintette, vagy hogy buccari kerület (Szádrév, ma: Bakar) mikor és hová tartozott, illetve miért is engedte el az uralkodó a Magyar Tengermellék osztrákká tételének korábbi kísérletét. Az ekkor 5132

4 Eöttevényi Nagy Olivér: Fiume és a Magyar Tengermellék, A Tenger, A Magyar Adria Egyesület Közlönye, 1913. január-február, 4.

5 A statútumalkotás jogára is kiterjedt az önigazgatás, mint a mintát adó Raguzában.

6 Erre utal a címer jelszava is: indeficienter - kiapadhatatlan/kiszáradhatatlan.

7 http://lexikon.katolikus.hu/F/Fiume (Letöltés ideje: 2017. 12. 22.)

8 Idézi: Schnierer Gyula: Fiume múltja és jelene, Nemzetgazdasági Szemle, 1882/3, 37. 
lakossal ${ }^{9}$ bíró városban és kerületében újjászervezett közigazgatás élére a Magyar Királyi Udvari Kancellária alá rendelt Fiumei és Magyar Tengermelléki királyi kormányzó került. Természetesen a jogrendszer, illetve a fiumei alkalmazandó jog szempontjából is megkerülhetetlen a „betestesítési oklevél”, amely ekképp rendelkezik: „statutumai használatában Fiume is - de az ország törvényei sérelme nélkül - továbbá is megmaradjon; a mennyire pedig azok némelly pontjai Magyarország, s a hozzákapcsolt országok és tartományok rendszerével nem egészen egyeznének meg: azok küldöttség által megvizsgáltatni, a legfelsőbb kir. helybenhagyás végett fölterjeszteni rendeltettek". ${ }^{10}$ Mivel Magyarország a kor felfogása szerint mégiscsak ,jogállam” volt, ezért a területgyarapodást törvénybe kellett foglalni. Erre hosszas időhúzás után 1807-ben került sor, amikor megszületett az Országgyủlés Fiuméról szóló IV. törvénycikke, amely a fiumei kormányzónak a förendek tábláján, Fiume város követeinek pedig a kk. és rr. ${ }^{11}$ tábláján biztosított részvételt, és az országhoz tartozónak nyilvánította a várost és kikötőjét.

Az első magyar korszaknak rövid francia uralom vetett véget, amely után Bécs egy Illír Királyság létrehozásával próbálkozott, így 1822-ig kellett várni a Szent Koronához való visszatérésre. E királyság és még inkább az ezt megelőző francia fennhatóságú Illír Tartomány puszta léte azonban, bármilyen kérészéletủ is volt - viszonylagos önállósága okán - mély nyomot hagyott a felerősödő horvát (délszláv) mitológiában. 1822. július 1-jén hozott felséghatározatával (1822-diki julius 1-jén költ k.k. leirat ${ }^{12}$ ) I. Ferenc császár és király visszacsatolta Magyarországhoz Fiumét (és kerületét), a Littorale Hungaricummal (Magyar Tengermellék) együtt..$^{13}$ A magyar Országgyủlés újfent nekirugaszkodott, de Fiume és a Tengermellék státusának normatív rendezésére csak az 1827. évi XIII. törvénycikkel került sor, amely „a Száván tuli országrészek és a magyar tengermellék viszszakeblezéséröl" szólt.

1848 a Tengermelléken is a nemzeti gondolat és a polgári átalakulás jegyében indult, de aztán mindent megelőzött és felülírt a nagyhorvát nacionalizmus és udvarhűség. A felelős magyar kormány ezt megelőző utolsó próbálkozását a márciusban megindult társadalmi és politikai változások törvényes mederben tartására - Fiume vonatkozásában - az áprilisi törvények jelentették. Az 1848. évi XXVII. törvénycikk Fiume és Buccari szabad tengerkereskedési kerületekről a törvény előtti egyenlőség elvét valló, modern közigazgatást megvalósítani igyekvő felelős kormány törekvéseiből egyértelmüen következett. A nyár végére azonban a helyzet gyökeresen megváltozott. Bár e törvényi változások a társadalmi és gazdasági előrelépés jegyében születtek, a birodalmi határőrezredekbe szervezett horvát szoldateszka és a mögötte álló osztrák birodalmi lobbi némi hezitálás után a nyílt erőszak oldalára állt, és törekvéseiket egyre inkább Josip Jelačić, a törvényes előírások megsértésével kinevezett - majd sorozatos jogsértő magatartása miatt tessék-lássék felmentett - horvát bán jelképezte. Jelačić még az

9 NAGY Adrienn: Fiume dualizmus kori oktatásügye és a Magyar Királyi Kiviteli Akadémia, Korall, 2014/56, 119.

10 CSÁsZÁr Ferenc: A fiumei kikötő, II. Füzet. Budán a’ M. Kir. Egyetem betüivel MDCCCXLIII, 23.

11 Karok és Rendek.

12 CSÁSZÁR: i. m., 24.

13 FEST Aladár: Fiume Magyarországhoz való kapcsolásának előzményeiről és hatásairól, Századok, 1916/4-5, 264. 
áprilisi törvények társadalmi változásokat legalizáló rendelkezéseit is a sajátjaként „,adta el” Horvát-Szlavónországban.

1848. augusztus 30-án Josip Bunjevac - a hivatalosan még mindig a báni méltóságából és egyéb beosztásaiból történt királyi felmentésének hatálya alatt lévő - Josip Jelačić nevében ultimátumot intézett Erdődy János fiumei kormányzóhoz, aki a jórészt reguláris túlerőt látva nem vállalhatta az ellenállást a fiumei nemzetőrökkel. A kormánynak Fiume katonai megerősítését célzó törekvéseit a bécsi hadvezetés különböző indokokkal korábban sikeresen meghiúsította. A másnap, augusztus 31-én annexiós céllal támadó parancsnok kijelentette, hogy „a cs. és kir. Felség és a slavon-dalmát-horvát hármas országok nevében Fiumét tettleg elfoglalja" ${ }^{14}$ A megszállást követően Erdődy kormányzót távozásra kényszerítették (a magyar kormányzóság működését felfüggesztették), Bunjevac pedig vérszemet kapva már arról rendelkezett, hogy a horvátországi Fiume vármegye székhelye a város legyen, egyidejűleg „ö Felsége nevében” közzétette kiáltványát, amelyben a Fiumét illető helyhatósági kiváltságok és intézmények fenntartására tett ígéretet. Történt mindez a magyar Szent Korona egyik országában és ugyanazon korona corpus separatumában.

Ezután hosszú ex-lex állapot következett. Az új gazdák az osztrák fegyverek árnyékában egyre inkább horvát várossá próbálták formálni Fiumét (pl. a horvát nyelvű oktatás erőltetése az olasz gimnázium horvát tannyelvűvé tételével), és erről nem is tettek le mindaddig, amíg Ausztria belső és külső pozíciói nem gyöngültek meg eléggé ahhoz, hogy Bécsben belássák: a magyarok cselekvő részvétele nélkül nem tudják megőrizni birodalmuk egységét. Az 1867-es osztrák-magyar kiegyezés után a horvátok körül Zágrábban és Fiuméban is elfogyott a levegő, a magyarokat gyöngítő és a Monarchia egységét veszélyeztető horvát önállósodási politika egyelőre lekerült a napirendről.

Nincs most idő és lehetőség annak a huzavonának a bemutatására, ami Fiume státusa körül (ekkor is) kialakult. Ez nyilván a magyar-horvát viszonynak is függvénye volt. Itt és most csak annyit kívánunk megjegyezni, hogy az 1868-as magyar-horvát kiegyezéssel, ami engedményt lehetett, azt a horvátok megkapták. (Magyarország végleg lemondott a három alsó-szlavóniai vármegyéről, illetve a korábbi Magyar Tengermellék nagy részéről, a honvédség közös - magyar - vezényleti nyelvéről, és beligazgatásában Horvátország teljes autonómiát kapott stb.), de mindez nem volt elegendő ahhoz, hogy Fiumét a horvátok elengedjék. Ráadásul a magyar-horvát kiegyezési törvény magyar (a Fiuméről is szóló 66. §) és horvát változata eltértek egymástól - további vég nélküli vitákat generálva a „fiumei folt” eredetéről és felelőseiről.

A város státusáról, igazgatási kérdéseiről (ide nem értve azt, hogy a város a Magyar Királyságon belül Horvát-Szlavonországhoz vagy Magyarországhoz tartozik-e) háromoldalú ún. regnicolaris bizottságokban kellett volna megállapodni, de ez a fennhatóság tárgyában kompromisszumképtelen horvát álláspont miatt nem bizonyult járható útnak. A horvát küldöttség végül azt javasolta, hogy amennyiben az általa képviseltek nem akceptálhatóak a másik két fél részéről, „addig is, míg e kérdésnek végleges megoldását a siker

14 JАКАв Elek: A magyar Fiume, Nyomtatott a Magyar Királyi Egyetemi Könyvnyomdában, Budapest, 1881, 26. 
nagyobb valószínüségével meg lehetne kisérleni...”, ${ }^{15}$ napolják el a következő ülést, Fiumét pedig provizórikusan igazgassa a magyar kormány.

Ez az elképzelés a fiumei törekvésekkel is egyezett, mivel a kikötővárosban az elmúlt két évtizedben már keserű ízelítőt kaptak a horvát fennhatóságból. Bár az ideiglenesség nem szerepelt a fiumei tervek között (mivel a korábbi státus quo visszaállítását tartották megnyugtató megoldásnak), a magyar kormányzás felemás visszatérése is megfelelt kompromisszum gyanánt, amennyiben a horvátok kiszorulnak Fiume igazgatásából. Ennek megfelelően a három bizottság utolsó közös tanácskozásán a magyar és fiumei küldöttek a provizórium terve mellett foglaltak állást. A provizórium részleteit a kormány kidolgozta, és azt mind a Szábor, mind a magyar Országgyưlés jóváhagyta. 1870. július 28-án megjelent a két királyi dokumentum, mely Fiuméban megszüntette az 1867 óta fennálló királyi biztosságot és elrendelte a provizóriumot. Ifj. gróf Zichy József fiumei és magyar-horvát tengerparti kormányzóvá kinevezésével hivatalosan is visszatért a magyar államhatalom a kikötővárosba.

\section{Jogalkalmazás és Fiume}

Elérkeztünk a Fiuméban alkalmazandó jogszabályok problematikájához, amellyel rövid időn belül szembesülnie kellett a kormányzatnak mind általánosságban, mind a nemzetiségi egyenjogúság tárgyában hozott 1868. évi XLIV. törvénycikk vonatkozásában is. Nyilvánvaló, hogy a jogalkotás/jogalkalmazás kérdése tágabb összefüggések eredményeképp kerülhetett nyugvópontra. Ezért elsőként az alkotmányos keretek áramvonalasítása kérdését kell röviden áttekintenünk. A magyar Szent Koronához csatolt külön testet (separatum sacrae regni coronae adnexum corpus) képező Fiuméra vonatkozó provizórium nem jelentett mentséget a tekintetben, hogy a magyar törvényhozásnak és a magyar kormánynak a város fejlődését elősegítő, átlátható és modern jogszabályi környezetet kellett kialakítani. Ennek első csírái már a magyar-horvát kiegyezés után megjelentek, de nagy részük a provizórium idejére esett.

A provizórium egy királyi rendelet (pátens) formájában jelent meg. Ez a rendelet szó szerint megegyezett a magyar kormány tárgyi előterjesztésével. Feltehetően így lehetett az integráló személyiségként megjelenő uralkodót (akinek egyébként e körben is fontos közjogi funkciói voltak, pl. a kormányzó kinevezése) bekapcsolni a folyamatba, és ez ellen sem a magyar kormány, sem Horvátország nem emelt szót. Talán a választott megoldás ideiglenessége is indokolta ezt a jogforrástípust. Senki sem gondolta, hogy Fiume státusa már nem fog változni a Monarchia és benne Magyarország összeomlásáig.

A provizórium viszonylag nagyvonalúan a magyar kormányra bízta Fiume igazgatását. Ennek jogszabályi kereteit azonban csak úgy lehetett kialakítani, hogy Fiume élhessen statútumalkotási jogával, és az önkormányzatiság ezen alapdokumentuma mintegy kiegészítse a központi (budapesti) kormány és az Országgyűlés jogszabályait.

15 Joó Gyula: A másfélszázados polémia Fiume birtokáért = Emlékkönyv a Kecskeméten működő Egyetemes Református Jogakadémia fennállásának 100. évfordulójára (1831-1931), Egyetemes Református Jogakadémia Tanári Kara, Kecskemét, 1932, 253. 
Így az 1848 utáni első kormányzó egyik legfontosabb feladata volt, hogy a fiumei autonómia elsődleges dokumentuma legalább tervezeti szinten elkészüljön, hogy a magyar kormány azt minél előbb el tudja fogadni. A kormány 1872. április 20-i ülésére hivatalos volt a fiumei kormányzó is, aki ekkor annak a véleményének adott hangot, hogy a Statútum elfogadásával a közigazgatás rendezése beteljesedhet. A kormány több ponton figyelembe vette a fiumei kéréseket is (pl. virilizmus mellőzése), és végül 1872. június 1-jei dátummal hirdette ki „Fiume szabad város és kerülete Statutumát” (a város hivatalos nyelvén, olaszul: Statuto della libera Citta di Fiume e suo Distretto, továbbiakban: Statútum). Az egykor volt, viszonylag nagy kerület - a Magyar Tengermellék - 1872-re azonban már a múlt ködébe veszett: csak Plasse, Cosala, Drenova alközségek tartoztak Fiuméhoz. ${ }^{16}$

\section{A "készen kapott jogszabályok" kérdésköre}

Az autonómia természetesen nem dunsztos üvegként kapcsolódott a magyar jogrendhez, de jelentősen bonyolította a helyzetet, hogy ugyan a Statútum nem állhatott ellentétben a magyar törvényekkel, de ezek egy része történelmi okokból következően nem volt hatályban Fiuméban és kerületében. Bár autonómiája miatt Fiume önállósága nagyobb volt, mint a magyarországi törvényhatóságoké általában, ennek ellenére a törvényhatóságokról szóló 1886. évi XXI. törvénycikk szükségesnek tartotta kitérni a korábbi szabályozás hatályosságára és akként rendelkezett, hogy „Fiume város és kerület törvényhatósági ügyei, a törvény ujabb rendelkezéséig, a fennálló törvényes gyakorlat szerint intéztetnek”. ${ }^{17}$ Ezzel a „szabályozással” már találkozhatott a kor jogkereső közönsége, ugyanis a magyar és a báni kormányzat a Fiumei Királyi Törvényszék felállításáról szóló közös rendeletben 1871-ben kimondta, hogy a „törvényszék hatósága alá esö ügyekre a fennálló törvények, szokások és rendeletek továbbra is érvényben maradnak". ${ }^{18}$

Mit is jelentett a fennálló törvények, szokások, rendeletek hármas felsorolása? Ezek között a jogforrások között elsősorban a Bach-korszakban alkotott jogszabályokat találunk, de olyan „nagyágyú” is volt köztük, mint a Code civil des Français, amely a napóleoni megszállás és Illír Királyság idejéből maradt fenn, és alkalmazása tengerjogi ügyekre korlátozódott. Egyes 1848 előtti magyar jogszabályok is alkalmazásra kerültek: például az 1843-ból származó magyar kormányzósági rendelet, a „Regulamentum in merito manipulationis librorum fundualium, inscriptionum et intabulationum pro libero Districtu Fluminensi Altissimo Loco Ratihabitum, Ope B. C. Intimati Exelsi Consilii R. Locumt. Hungarici

16 A magyar-horvát kiegyezéssel elégedetlen horvátoknak nyilván az sem tủnt fel, hogy szép lassan, lépésről lépésre az egykor volt Magyar Tengermellék, 20 km² kivételével, már Horvátország fennhatósága alá került.

17 1. §, IV.

18 A magy. kir. ministerelnöknek, a magy. kir. igazságügyministernek és Horvát-, Szlavon-Dalmátországok bánjának, 1871. sept. 14-én kiadott rendelete a fiumei kir. törvényszék felállitása s hatóságának ideiglenes szabályozása tárgyában.

„11. §. A fiumei kir. törvényszék hatósága alá eső területen fennálló és a 3. §-ban érintett ügyekre vonatkozó törvények, szokások és rendeletek, a mennyiben a jelen rendelet és a következő \$-ban érintett ügy vitel határozatai mást nem szabnak meg, továbbra is érvényben maradnak." 
D. D. 27 Decembris 1843 No. 46429 Dimissum", amelyet telekkönyvi ügyekben alkalmaztak. A Bach-korszakból pedig olyan fontos kódexek is hatályosultak, mint az Osztrák Általános Polgári Törvénykönyv (OPTK). A Fiuméban 1853. május 1-je óta hatályos OPTK egyébként túlnyomórészt a provizórium alatt is hatályban maradt.

A korábbi „törvények, szokások, rendeletek” tekintetében tehát látszólag minden zökkenőmentes volt, egyelőre további alkalmazásuk volt a természetes. Ugyanakkor nyilvánvaló volt, hogy ezeket a jogforrásokat előbb-utóbb a magyar jogrenddel összhangba kellett hozni. Ez még akkor is így volt, ha a korszakra nem feltétlen feleltethető meg az egy ország - egy jogrendszer elve. A gyakori terület- és impériumváltozások miatt, illetve a korábbi feudális széttagoltság örökségeként a XIX. századi Európában szinte mindenütt jellemző volt ez a jelenség a különböző jogrendszerekben. Ugyanakkor a kor modernizálódó államaiban új, átfogó törvények jelentek meg az élet szinte minden területén, amelyekkel kapcsolatosan az adott állam érthető módon lépett fel az egységes jogalkotás/ jogalkalmazás igényével. Így volt ez Magyarországon is (pl. bűnvádi perrendtartás).

1883-ban (utoljára) még összeült a Fiume státusa egyes kérdéseinek rendezésére hivatott ún. regnicolaris bizottság, de konszenzusra nem tudott jutni, mert a horvát küldöttség lényegében már nem akceptált semmilyen véglegesnek gondolt és a horvát szupremáciát el nem ismerő megoldást. A magyar és a fiumei regnicolaris bizottsági küldöttség ugyanakkor egyetértett abban, hogy a Fiuméra vonatkozó szabályozás a "fennálló állami törvényekkel és berendezésekkel összhangba hozassék". ${ }^{19}$

A meglévő törvények, egyéb jogszabályok fiumei hatálybaléptetése (korabeli szóhasználat szerint: életbeléptetés), „összhangba hozása” az idő előrehaladtával egyre kevésbé állt a fókuszban, mert a figyelem egyre inkább az új jogszabályokra terelődött. Pedig a nemzetiségi törvény ebből a szempontból inkább ebbe az „összhangba hozandó” csoportba tartozott, hiszen 1867 és 1870 között Fiume státusa rendezetlen volt, és - ha az oktrojált horvát-osztrák korszakot illegitimnek is tekintve az 1848-ben megszakadt államjogi helyzet folytatását fogadjuk is el kiindulási alapnak - az ebben az időszakban alkotott jogszabályok fiumei alkalmazása azért nem volt automatikus és minden kérdéstől mentes.

A fentiekből kifolyólag a „készen kapott jogszabályok” problematikájára még viszszatérünk, épp a nemzetiségi törvény kapcsán.

\section{A provizórium bevezetése után alkotott magyar jogszabályok és Fiume}

A döntő kérdés itt nem másról szólt, mint arról, hogy a kormány, illetve az Országgyűlés milyen megoldást preferál a jövőben meghozandó (és részben a meglévő) magyar törvények fiumei hatálybaléptetéséhez. Jelen esetben a kérdést és a választ egyelőre

19 SzÁntó Andor, KRÁl Vilmos: Fiume államjogi helyzete, Vas Tivadar Könyvnyomdája, Budapest, 1901, 94. 
egyszerủsítsük a törvényekre, tekintettel arra, hogy a kormány és tagjainak rendeletei vonatkozásában a provizórium nem hagyott kétséget a tekintetben, hogy miután a kormány igazgatja Fiumét, jogszabályokat is alkothat e tevékenységi körben.

Három álláspont kristályosodott ki: a magyar Országgyűlés törvényei ipso facto alkalmazandóak Fiuméban, vagy külön hatályba léptető rendelkezésre van szükség, illetve minden alkalommal szükséges a hatálybaléptetéshez Fiume beleegyezése. Az ipso facto alkalmazandóság mellett az szólt, hogy amennyiben a kormánynak joga van Fiuméra nézve a provizórium okán rendelkezni, akkor a felette álló törvényhozás ezt minden inkorporálás nélkül megteheti. Ez az érvelés alkotmányos szempontból elég meggyőző. Ugyanakkor megjegyzendő, hogy - mint tudjuk, ugyan a kormány előterjesztésére, de Ferenc József királyi legfelső kézirata rendezte ideiglenesen Fiume státusát. E legfelső kézirat - bár a jogforrási rendszerben való elhelyezkedése adhat okot további vitákra - kétségtelenül tartalmazott olyan szabályozási tárgyakat, amelyekre az Országgyülésnél volt hatáskör a szükséges törvényi szabályok megalkotására. A külön hatálybaléptető rendelkezés kizárólagossága mellett érvelők abból indultak ki, hogy a kormány ráruházott hatalmat képvisel ebben a viszonyrendszerben. A felhatalmazás mögött felmutatható volt nemcsak a magyar Országgyủlés, de a horvát Szábor egyetértő határozata is. Ebből - ebben a logikában - az következett, hogy a magyar törvényhozást nem illeti meg a Fiuméra vonatkozó, önálló és inkorporálás nélküli törvényalkotás (a horvát törvényalkotás itt fel sem merül). Ehhez az állásponthoz jó muníciót adott a fentiekben is említett országgyủlési határozat, amely szerint a „minisztérium Fiume várost és közigazgatását vegye át”. A közös eredetủ felhatalmazás alanya tehát a magyar kormány, amely egyrészt nem mellőzhető a hatálybalépés folyamatában, másrészt, miután az általános jellegű törvények a sajátos fiumei viszonyokat nem vehetik figyelembe, a kormányrendelet töltheti be azt a funkciót, amellyel testre lehet szabni a szabályozást. ${ }^{20}$ Kétségtelen, hogy e felfogás - a legitimáció erősítését célozva - a Szábort is beemeli érvrendszerébe. Az pedig, hogy a jogszabályi hierarchia nem igazodási pont, a korszakban még nem jelentett „eretnekséget”. Erre azért is kell felhívni a figyelmet, mert abban szinte mindenki egyetértett, hogy a hatálybaléptetés nem egy kétmondatos jogforrás, hanem a kérdéses törvény áramvonalasítása, kiegészítése, szủkítése stb. - azaz sok tekintetben quasi önálló szabályozási jogkör - a fiumei sajátos viszonyokra való tekintettel (azt senki sem gondolta komolyan, hogy a kormány „játéktere” mindössze annyi lenne, hogy hatályba lépteti változatlan formában a törvényt vagy sem). Összefoglalva: a magyar törvényhozás nem mondott le Fiume igazgatásáról olyan értelemben, hogy az csak a kormány joga és kötelezettsége lenne. Ez - a fentieken túl - ellentmondott volna történeti alkotmányunk azon 1848-as vívmányának is, miszerint a kormány tevékenységében felelős az Országgyủlésnek. ${ }^{21}$

Az elvi éllel folyó vitát árnyalta, hogy az Országgyủlés - bár nem feltétlen következetesen, de - általában azt a szabályozási módot választotta, hogy az egyes törvények végén helyet kapott az ún. fiumei (mindig hasonló formátumban és tartalommal szerkesztett) paragrafus, amely - általában a szövegtest végén - elöírta az adott törvény fiumei alkalmazását. A „kormány mindenek-felettiségét” valló felfogás képviselői is

20 Uo., 94.

21 Ld. bőv.: 1848. évi III. törvénycikk a független magyar felelős ministerium alakításáról. 


\section{ERDÉLYI JOGÉLET}

elismerték az Országgyủlés jogát arra, hogy e kifejezett törvényi utasítás esetén a hatálybaléptetés nem tagadható meg. Itt is kérdés maradt azonban a tartalmi változtatás szabadsága. Ugyanakkor törvényi utasítás hiányában a kormánynak vindikálták a jogot a tekintetben, hogy kifejezett törvényi előírás nélkül hatályba lépteti-e Fiuméban az adott törvényt vagy sem. ${ }^{22}$

További fontos kérdés - amely már a kortársaknál is felvetődött -, hogy meddig marad hatályban a hatálybaléptető rendelet? Idő és hely hiányában erre a problémára most részletesen nem térünk ki, már csak azért sem, mert ezt maga az élet oldotta meg 1918 végén a katonai megszállás és a későbbi trianoni békediktátum útján, hiszen a provizórium vége egyben a Magyar Királyság határait is szétfeszítette.

A harmadik álláspont, miszerint minden törvény esetében szükséges a hatálybaléptetéshez Fiume beleegyezése, nem volt jellemző a provizórium szűk 50 esztendejére, csak legfeljebb annak második felére. Okai között pedig elsősorban kell megemlíteni, hogy a millennium után egyre inkább megbomlott a fiumei-magyar egység. E mögött azonban számos eredő állt. A teljesség igénye nélkül említhetjük a bevándorlás miatt teljesen megváltozott összetételü lakosságot, az olasz irredenta elképzelések fiumei szárba szökkenését, a központosító vagy annak vélt, illetve a jogrendszer egységesítését célzó kormányzati intézkedéseket. Röviden felidézve a történteket, a fiumei képviselőtestület - annak ellenére, hogy a fiumei országgyülési képviselő korlátozás nélkül vett részt az Országgyủlés munkájában - jogalkotó tényezővé kívánta átpozicionálni Fiume státusát, és ezért a telekkönyvi betétek szerkesztéséről szóló 1886. évi XXIX. törvénycikkel öszszefüggésben tartandó egyeztető értekezletre a kért két fiumei résztvevő kiküldését a képviselőtestület visszautasította azzal, hogy álláspontja szerint a képviselőtestület joga a Fiuméban bevezetendő törvényekről dönteni, és e hatáskörét nem engedi elvonni, illetve a miniszterelnökkel közvetlenül kíván kapcsolatot tartani e kérdésekben (is). ${ }^{23} \mathrm{~A}$ bünvádi perrendtartás (1896. évi XXXIII. törvénycikk) fiumei hatálybaléptetése kapcsán is egyértelművé vált az a fiumei álláspont, hogy a ius consultandi már nem elegendő: 1897. szeptemberi memorandumában (feliratában) Fiume már azt követelte, hogy minden egyes törvény fiumei hatálybaléptetése előtt kérjék ki „, a képviselőtestület helyeslö, módositó vagy megtagadó véleményét”. ${ }^{24}$ A nyílt konfrontációt a képviselők többségének lemondása füszerezte, és a válság biztos jeleként Giovanni de Ciotta polgármester és Batthyány Lajos kormányzó is megvált tisztségétől.

Ezt a válságot csak Széll Kálmán miniszterelnöksége alatt sikerült kezelni, elsősorban a közigazgatási reform fiumei igényeket is figyelembe vevő kompromisszumos átszabásával, de a fiumei elit és a magyar kormány ettől fogva gyanakodva méregették egymást: odalett a felhőtlen jó viszony és a bizalom légköre.

22 Ld. bőv.: SzÁnTó, KRÁL: i. m. 95.

23 Ld. bőv.: S. PAllós Piroska: Támadás Fiume autonómiája ellen. A fiumei közigazgatási bizottság 1897. évről készült jelentése nyomán, Közép-Európai Közlemények. Történészek, geográfusok és regionalisták folyóirata. 2013/3, 51.

24 SzÁntó, Král: i. m. 101. 
Fiume és a nemzetiségi egyenjogúság tárgyában hozott 1868. évi XLIV. törvénycikk

\section{A hatálybaléptetés gyakorlati kérdései}

A Fiumére vonatkozó joganyag átfésülésére, deregulálására, illetve a hatálybaléptetés technikájának, módozatainak egységesítésére végül nem került sor.

Így különböző megfogalmazásokkal történtek a modern jogállamban megkívánt jogegység érdekében eszközölt hatálybaléptetések. Álljon itt két jellemző példa a gyakorlat szemléltetésére: az új büntetőtörvénykönyv (Csemegi-kódex, 1878. évi V. törvénycikk) hatálybalépésének részletes szabályairól - nemcsak Fiume okán, hanem általánosságban is - eleve külön törvényben rendelkeztek. Ez tálcán kínálta a lehetőséget, hogy a fiumei hatálybalépést is e jogszabályban rendezze a jogalkotó. Az Országgyülés végül a magyar büntető-törvénykönyvek (1878: V. törvénycikk és 1879: XL. törvénycikk) életbeléptetéséről szóló 1880. évi XXXVII. törvénycikk 48. §-ában kimondta, hogy „Fiumét illetöleg felhatalmaztatik az igazságügyminister, hogy a magyar büntetö-törvénykönyveket külön rendelettel léptesse hatályba, és ezen rendeletben a kihágásokat illetöleg, az ottani viszonyoknak megfelelő módositásokat megtehesse". Erre és a módosításokra végül egy hónappal a Magyarországon történő hatálybalépés után került sor. A Csődtörvényről szóló 1881. évi XVII. törvénycikknél a fiumei hatálybaléptetést érintő szabályozás a következő volt: "felhatalmaztatik az igazságügyminister, hogy a jelen csődtörvényt külön rendelettel léptesse hatályba, és ezen rendeletben az ottani viszonyoknak megfelelő módositásokat megtehesse". ${ }^{25}$

Természetesen ezek a példák a gyakorlatban nem minden esetben voltak jellemzőek. Az Országgyülés azon törvényeknél, amikor a szabályozás tárgya részben vagy egészben maga Fiume volt vagy valamely Fiuméban megvalósuló állami (vagy államilag támogatott) intézmény, beruházás stb., akkor a Szent Korona országainak közös budapesti kormányzata és/vagy törvényhozása e minőségében járt el, így ebben a körben nem volt „fiumei paragrafus” (záradék). Ekkor ugyanis Fiume egy tekintet alá esett Magyarország (sőt a horvátokkal közös ügyek tárgyalása esetén a Magyar Királyság) más településeivel, intézményeivel, vállalkozásaival, beruházásaival. Például az 1900. évi XXXIV. törvénycikk több állami beruházás költségeinek fedezéséről különböző beruházások pénzügyi fedezetéről döntött, és ezek között csak a „dock-medence” 1700000 koronás támogatása kapcsán volt érintett a város. Nem találunk „fiumei paragrafust” a fiumei m. kir. állami rendőrségről szóló 1916. évi XXXVII. törvénycikk esetében sem.

A kötelező hatálybaléptetés kizárólagossága ellen (ergo az ipso iure alkalmazhatóság mellett) szól egy késői példa, amely szerint 1912-ben egyenesen kiveszik a várost egy törvény hatálya alól (a városok fejlesztéséről szóló 1912. évi LVIII. törvénycikk 31. §-a - korlátozva a törvény hatályát -, azt nem terjesztette ki „Fiume szabad városra és kerületére").

Összefoglalva a hatálybaléptetéssel kapcsolatos elméleti vitákat és az ismertetett gyakorlatot, szilárd álláspontunk, hogy talán jobb lett volna a deregulációt, az „összefésülést” még az optimista és baráti légkörben, az 1870-es években véghezvinni, és ezt követően egyen fiumei paragrafussal és - ha szükséges - egyértelmű felhatalmazással lett volna lehetséges az adott törvény kormány általi érdemi változtatása vagy kiegészítése. 


\section{A nemzetiségi törvény és Fiume}

A nemzetiségi egyenjogúság tárgyában hozott 1868. évi XLIV. törvénycikk - szemben a „politikai tekintetben is külön nemzetet képező” Horvát-, Szlavón- és Dalmátországokkal, ${ }^{26}$ ahol a törvény maga zárta ki a társországokban való alkalmazást - fiumei hatályosulása nem volt teljesen egyértelmű. A „fiumei paragrafus” természetszerüleg hiányzott a törvényből, ugyanis abban az átmeneti időszakban fogadták el, amikor még nem dőlt el Fiume státusa. Ezért - mint arra már utaltunk - inkább abba a csoportba kell sorolnunk e jogforrást, mint azokat a joganyagokat, amelyeket a provizóriummal „készen kapott” Fiume.

Textuálisan értelmezve a nemzetiségi törvényt a következőkre juthatunk:

- A nemzetiségi törvény szentesítésére 1868. XII. 6-i dátummal került sor, és az ezt követő napon ki is hirdették az Országgyűlés mindkét házában. A törvény Preambuluma a következőképpen rendelkezett: „Minthogy Magyarország összes honpolgárai az alkotmány alapelvei szerint is politikai tekintetben egy nemzetet képeznek, az oszthatatlan egységes magyar nemzetet, melynek a hon minden polgára, bármely nemzetiséghez tartozzék is, egyenjogú tagja; minthogy továbbá ezen egyenjogúság egyedül az országban divatozó többféle nyelvek hivatalos használatára nézve, és csak annyiban eshetik külön szabályok alá, a mennyiben ezt az ország egysége, a kormányzat és közigazgatás gyakorlati lehetösége s az igazság pontos kiszolgáltatása szükségessé teszik;"

- A nemzetiségi törvény 29. §-a, miként arra már utaltunk, kizárta a horvátországi alkalmazást, és megerősítette a horvát nyelvhasználatot az Országgyủlés közös, magyarhorvát ülésein. Tény: a nemzetiségi törvényt a későbbiekben nem módosították például olyan értelemben, hogy fiumei alkalmazása kizárt, ebből azonban még nem tudunk levonni messzemenő következtetést a területi hatály szempontjából.

Óvatosabban eljárva, távolabbról indulva, másképpen is megközelíthetjük e kérdést. Az 1879. évi L. törvénycikk a magyar állampolgárság megszerzéséről és elvesztéséről kimondta, hogy „A magyar korona összes országaiban az állampolgárság egy és ugyanaz” (1. §). E paragrafushoz füzött indoklás pedig erre ráerősítve akként fogalmaz, hogy „megjegyeztetik, hogy mivel a magyar korona országai egy és ugyanazon államot képeznek, bennük az állampolgárság is csak egy és ugyanaz lehet" (Indokolás 1. §-hoz). Tette ezt olyképpen, hogy nem tartalmazott „fiumei paragrafust”. Ezen túlmenően, jelezve, hogy a Magyar Királyság három entitásból áll, kimondta: „A 8., 9. és 10. § értelmében eszközlendő honositás tárgyában azokra nézve, a kik Magyarország és Fiume területén laknak: a belügyminister, azokra nézve, a kik Horvát-Szlavonországok területén laknak, a horvát-szlavon-dalmát bán illetôleg a határvidéki országos hatóság határoz s azon esetben, ha a kérelemnek helyt ad, az illetö részére honositási okiratot állit ki, minden egyes eset azonban a kellö nyilvántartás végett a ministerelnök tudomására hozandó." ${ }^{27}$ Ebben - az analógiára épülő - logikában a nemzetiségi törvény fiumei hatályosulását sem lehet alappal megkérdőjelezni, mivel a három entitásból a törvény maga csak Horvátországot vonta ki a hatálya alól, illetve később se módosult e

26 29. §.

27 11. . 
tárgyat illetően olyan irányban, ami Fiume kivételére utalna. Ugyanakkor kérdőjeles, hogy a „készen kapott” törvények csoportja tényleg minden további intézkedés nélkül alkalmazandó jogforrásokból állt-e, és az analógia velük kapcsolatban megállja-e a helyét. A gyakorlat azt mutatja, hogy a válasz: igen. De nemcsak a gyakorlat (és a mindig vitatható analógia) áll ezen felfogás mellett. A korábbiakban kifejtetteken túl abból kell kiindulnunk, hogy a Fiumét sújtó osztrák-horvát katonai megszállás, majd az ennek árnyékában megvalósult horvát annexiós kísérletek ex-lex voltához nem férhet kétség. Ebből következően, ha az 1848 augusztusát megelőző legitim időszakban a fiumei alkalmazás nem lett volna kérdés, akkor igazából nem lehetett kérdés a provizórium bevezetését megelőzően és azután sem. Gondoljunk csak a már említett és az áprilisi törvények közé sorolt 1848. évi XXVII. törvénycikkre, amely a Fiume és Buccari szabad tengerkereskedési kerületekről rendelkezik.

E törvényben egyetlen árva szóval sem utal semmi arra, hogy a fiumei (és pláne a buccarii) alkalmazás érdekében még lenne jogalkotási teendő (az uralkodói szentesítést leszámítva). Ez nem is lehetett másként, mivel 1848 előtt ez az eljárás ebben a formában nem volt a rendszer része. Ugyanakkor e törvény kifejezetten a két városról és kikötőikről szól, amelyek tehát szabályozási tárgyai az adott jogforrásnak, így a képet némileg árnyalja, hogy az ilyen és ehhez hasonló törvényekhez - nyilván más okból, de - általában a provizórium alatt sem illesztettek „fiumei paragrafust”.

\section{A nemzetiségi törvény a fiumei hétköznapokban: oktatás}

Az elméleti megközelítést követően álljon itt néhány példa arról, hogy valójában miként is került alkalmazásra Fiuméban a nemzetiségi törvény, illetve annak egyes konkrét előirásai. A nemzetiségi törvénynek az oktatással összefüggő nemzetiségi jogokat garantáló szabályai Fiuméra és kerületére az általánosságokon túlmenően több okból is alkalmazandóak voltak. Egyészt a provizóriumot kihirdető királyi legfelső kézirat akként rendelkezett, hogy a városi oktatásügy a magyar Vallás- és Közoktatásügyi Minisztérium (VKM) és a magyar (közös) Országgyủlés irányítása alá kerüljön. Figyelemmel Fiume lakosságának nemzetiségi összetételére, az olasz nyelvủ többségi lakosság mellett nagyszámú horvát, szlovén, német és egyéb nemzetiségủ személy is élt a városban és kerületében. Az államnak pedig a nemzetiségi törvényből (is) fakadó feladata volt a következő: „Az állam s illetőleg a kormány által már állított, vagy a szükséghez képest állítandó tanintézetekben a tanítási nyelvnek meghatározása, a mennyiben erről törvény nem rendelkezik, a közoktatási minister teendőihez tartozik. De a közoktatás sikere, a közművelődés és közjólét szempontjából az államnak is legfőbb czélja levén; köteles ez az állami tanintézetekben a lehetőségig gondoskodni arról, hogy a hon bármely nemzetiségü, nagyobb tömegekben együtt élő polgárai az általok lakott vidékek közelében anyanyelvökön képezhessék magukat egészen addig, hol a magasabb akadémiai képzés kezdődik." ${ }^{28}$ 
Az állam fent idézett törvényből is folyó iskolaalapítási jogának gyakorlása első megnyilvánulási formája volt az első magyar tanítási nyelvủ népiskola megnyitása 1875-ben. Ezt leginkább „Fiume város polgárainak köz-és magánérdekei” indokolták. ${ }^{29} \mathrm{Ez}$ nem jelentett azonnal és oktrojáltan 100\% magyar oktatási nyelvet, mivel közel 20 évnek kellett eltelnie ahhoz, hogy valóban és kizárólag magyar tanítási nyelvű legyen az oktatási intézmény.

A középiskolák terén kissé más volt a helyzet, mivel az egyetlen fiumei gimnázium a magyar adminisztráció visszatérte után is a néhány évvel korában ráerőltetett horvát tannyelven oktatott és felügyelete okán (a zágrábi tanfelügyelőség alá tartozott) is elkülönült státusa volt. Az olasz - és a később számottevővé váló magyar - ifjúság így nemzeti nyelven oktató gimnázium nélkül maradt. A kormány 1871-ben tüzoltásként egy olasz tannyelvű gimnáziumot hozott létre a községi alreáliskola továbbfejlesztésével (Fiumei Állami Felső Középtanoda - Regio Ung. Ginnasio Superiore di Stato in Fiume). Az iskola fenntartását a város is támogatta, cserébe személyzeti és felügyeleti kérdésekben bizonyos jogosítványokkal bírt. Újabb fejlemény volt a Középtanoda kormányzati átszervezése, amelynek következtében létrejöhetett a Magyar Királyi Állami Fögimnázium (Regio Ungarico Ginnasio Superiore dello Stato). Ez már olyan környezetben müködött, hogy pl. az 1902/1903-es tanévben a főgimnázium magyar anyanyelvủ tanulóinak aránya már elérte a 30\%-ot. Tanítási nyelve azonban még ekkor is szinte kizárólag az olasz volt. Ennek ellenére - miután a méltatlan állapotban lévő gimnáziumi főépület kiváltása rendeződött - a kormány engedélyezte az olasz középiskola (Civica scuola reale superiore) létesítését, amely 1912-ben kezdhette meg mủködését. És akkor - hely hiányában - nem beszéltünk a Magyar Királyi Állami Felső Kereskedelmi Iskoláról, amelyet egyenesen a kormányzó felügyelt, vagy a kereskedelmi tengerészeket képző, legendás Magyar Királyi Tengerészeti Akadémiáról (Regia Ungarica Accademia Nautica), amelyet csak „Nautica”-ként említenek a mai napig. Működésének utolsó 25 évében a hallgatók 2/3-a már magyar volt (Pecz Samu tervei alapján épült főépülete Fiume fölé magasodva ma is áll).

A kormány tehát élt a nemzetiségi törvény adta lehetőségekkel, de korántsem használta ki 100\%-osan az abban rejlő lehetőségeit. Például a horvát alsófokú közoktatás terén elkelt volna a központi intézkedés, mivel a város által fenntartott iskolákban teljes egészében visszaszorult a horvát nyelven történő oktatás, ugyanis Fiume csak az olasz nyelvủ oktatást preferálta. Az állami beavatkozás azért is szükséges lett volna, hogy a nyíltan magyarellenes horvát gimnázium negatív hatásait ily módon ellensúlyozni lehessen. Sajnos a központi oktatási kormányzat nem ismerte fel minden téren az iskolaalapításban rejlő lehetőségeket.

A város által fenntartott iskolákban egyébként a városi tanács akarata érvényesült, és az is tény, hogy számos fontos és a közoktatáshoz kapcsolódó törvények fiumei hatályba léptetése elmaradt. 1876 júniusától Fiume rendelkezett tanügyi statútummal, és bár hatályban volt a népiskolai közoktatás tárgyában született 1868. évi XXXVIII. törvénycikk is, e jogforrási megosztottság okán a magyar törvények csak az állam által alapított, illetve fenntartott állami iskolákban érvényesültek maradéktalanul, míg a Fiume által fenntartott iskolákra ez csak részlegesen volt igaz.

29 FEST Aladár: Fiume története = Magyarország vármegyéi és városai: Fiume és a magyar-horvát tengerpart, szerk. Sziklay János és Borovszky Samu, „Apollo” Irodalmi és Nyomdai Rt., Budapest, é. n., 116. 
Fiume és a nemzetiségi egyenjogúság tárgyában hozott 1868. évi XLIV. törvénycikk

\section{A hivatalos nyelvhasználat Fiuméban}

Az oktatás mellett a nemzetiségi törvény szabályozási tárgyai közül érdemes megvizsgálni a hivatalos nyelvhasználat kérdéseit. A nemzetiségi törvény 1-13. §-a rendezte a hivatalos nyelvhasználatot (törvényhatóságok, bíróságok stb.).

A kormány elsősorban a tervezett közigazgatási reform kapcsán, 1896-ban Dárday Sándort (a miniszterelnökség közjogi osztályának vezetőjét, jogtudóst, számos jogi publikáció szerzőjét, számszéki elnököt és országgyủlési képviselőt, a Jogtudományi Közlöny egyik alapítóját) küldte Fiuméba, hogy készítsen részletes jelentést a fiumei állapotokról, figyelemmel a jog világára. Dárday 1897 februárjában kiadott jelentésében ${ }^{30}$ azon véleményének adott hangot, hogy a fiumei autonómiát szabályozó Statútum előírásai és a virilizmus hiánya miatt Fiuméban „a demagóg soviniszta olasz elem jutott egyeduralomra”, és emiatt például a nemzetiségi törvénynek a kormányzati hivatalos nyelvre vonatkozó rendelkezései sem érvényesülnek, illetve a közigazgatási átszervezéstől azért idegenkednek a fiumei vezető körök, mert ez - véleményük szerint - a magyar nyelv használatának terjedését segítené elő. Dárday ugyanakkor kitért arra is, hogy a magyar törvények és rendeletek olasz fordításai gyenge minőségủek. Támogatta ugyanakkor, hogy a kereskedelmi forgalomban, különösen a MÁV által használt formanyomtatványok esetében elterjedjen a kétnyelvű ügykezelés.

Nem mehetünk el szó nélkül azon 1870 után megjelenő jogforrások mellett, amelyek egy-egy részterületen szabályozták a nyelvhasználati kérdéseket. A helyzetet némiképp bonyolította, hogy bár mindenki régóta egyértelműnek tekintette az olasz nyelv hivatalos voltát Fiuméban, ennek jogszabályi alapjai a múlt ködébe vesztek. Már 1848 előttről is találhatunk példákat arra, hogy eredet- vagy forrásmegjelölés nélkül hivatkoznak az olasz nyelv hivatalos jellegére [pl. a reformországgyủlések egyikén, 1843-ban Smaich Bertalan (buccari követ) szerint „nálunk nem a deák, hanem az olasz nyelv hivatalos”. Ezt megerősítendő, Horhy Mihály (fiumei követ) bizalommal kérte a karokat és a rendeket annak támogatására, hogy a „,nyelvre nézve Fiuméra az eddigi gyakorlatot fenhagyatni és ezt a jelen törvényben is kimondatni akarom". A későbbi (jog)történeti munkák is kész tényként kezelik az olasz nyelv hivatalos státusát. Például 1912-ben megjelent könyvében Nagy Ferenc, 1941-ben Csizmadia Andor, legújabban Koi Gyula erősítette ezt meg. Koi kifejezetten kitér az olasz nyelvű anyakönyvezés kérdésére is. ${ }^{31}$

Részterületet szabályozó kortárs jogforrás az 1871. szeptember 14-én kelt 3870. I. M. E. sz. a. miniszterelnöki, igazságügyminiszteri és horvát-szlavon-dalmát báni rendelet, amely arról intézkedett, hogy Fiuméban egy magyar királyi törvényszék (Tribunale) állíttatik fel, míg a járásbírósági (Pretura) teendőket ezen törvényszék elnöke által kirendelendő

30 ORDASI Ágnes: Dárday Sándor miniszteri tanácsos jelentése a fiumei kormányzati viszonyokról 1897. február 25., Lymbus Magyarságtudományi Forrásközlemények, Budapest, 2018, 533-557. 31 NAGY Ferenc: Magyar városi jog, A Rendezett Tanácsú Városok Polgármestereinek Országos Egyesülete, Budapest, 1912, 104-105. Hasonló tematikájú alapmű: Csizmadia Andor: A magyar városi jog. Reformtörekvések a magyar városi közigazgatásban, Győregyházmegyei Alap Könyvnyomdája, Kolozsvár, 1941. Kor Gyula: Az olasz közigazgatás-tudomány müvelői, és hatásuk a magyar közigazgatás-tudományra (1842-1942), Polgári Szemle, 2014/3-6, 263-283. 
egyik törvényszéki bíró végezte. Ezen, 1871. évi november hó 1. napján hatályba lépő rendelet kimondotta, hogy „A fiumei kir. biróság hivatalos nyelve: az olasz”. Miután a városi telekkönyvi hivatal is a királyi törvényszék alárendeltségébe került, így a hivatalos nyelv ott is az olasz lett.

Röviden kitér az állam, illetve Fiume hivatalos nyelvére az esküdtszékekről szóló 1897. évi XXXIII. törvénycikk is. Ez utóbbi törvény 4. §-a kimondta, hogy „Esküdt csak az a magyar honos férfi lehet, a ki az alaplajstrom egybeállitásának évében életkorának legalább huszonhatodikévét betöltötte és az állam hivatalos nyelvét, Fiuméban pedig az olasz nyelvet érti, azon irni és olvasni tud...”.

Szintén beszédes példa az 1907. évi XIX. törvénycikk az ipari és kereskedelmi alkalmazottaknak betegség és baleset esetére való biztosításáról, amely akként rendelkezett, hogy a „minisztérium” a törvényt Fiume város és kerületében az ottani viszonyok figyelembevételével rendeleti úton külön léptesse életbe. ${ }^{32}$ Ez meg is történt a m. kir. minisztérium 1910. évi 6.208. M. E. számú, december 20-án kelt rendeletével. E szerint az 1907. évi XIX. tc. rendelkezései Fiume városában és kerületében 1911. március 1-jén életbe léptek. Az ennek nyomán újonnan megszervezett fiumei kerületi munkásbiztosító pénztár könyveinek és számadásainak vezetésénél, valamint általában az ügykezelésnél az olasz nyelvet használhatta, azzal, hogy mind a magyar, mind az olasz nyelvü beadványokat köteles volt elfogadni és elintézni. Ugyanakkor a Fiumén kívül székhellyel bíró hatóságokhoz, az állami munkásbiztosítási hivatallal, illetve a budapesti országos munkás-betegsegélyző és balesetbiztosító pénztárral, valamint ennek helyi szerveivel félhasábosan magyar és olasz nyelven volt köteles kapcsolatot tartani.

Az utolsó példát, amely a nemzetiségi törvény fiumei alkalmazását bizonyítja, olyan körből merítettük, amely sok mindennek nevezhető, de a magyar törvények fiumei hatályosulása érdekében mindent megmozgató csoportosulásnak semmiképp sem. Az egyik legtekintélyesebb és legharcosabb, olasz nacionalista húrokat pengető La Difesa (Védelem) címủ időszaki lap, illetve a köré szerveződő ifjak, bár névleg kiálltak a magyar állameszme mellett, és - a nyelvi és kulturális olasz kötődés ellenére - Fiume jövőjét a Magyar Királyságon belüli autonómia keretei között keresték, kérlelhetetlen kritikáját adták a századfordulós Fiume és a magyar kormány kapcsolatának, a kormány intézkedéseinek. 1899-ben, az Autonóm Egyesületük alapszabályához kapcsolódó vitában felmerült, hogy óvakodjanak az olasz nemzetiség kifejezés használatától, mert az esetleg kirekesztően hat az egyesületi bázis szempontjából. Többen úgy vélték közülük, hogy a tagtoborzás és működés során a városi autonómiát, és nem a polgárainak etnikai hovatartozását kell hangsúlyozni. Végül az egyesületalapítók azon álláspontja győzött, hogy amennyiben a hivatalos országos statisztikákban olaszként tekintenek a fiumei lakosságra, az egyesület esetében is fel kell vállalniuk a tagoknak identitásukat. Ezt erősítette meg a polgármesteri címet (podestà) betöltő Michele Maylender is, aki egyenesen a nemzetiségi törvényre hivatkozott, amely szerinte a polgárok számára szabad választási lehetőséget nyújtott nemzetiségi hovatartozásukat illetően. ${ }^{33}$

32 1907. évi XIX. törvénycikk az ipari és kereskedelmi alkalmazottaknak betegség és baleset esetére való biztosításáról „Ugyszintén felhatalmaztatik a miniszterium, hogy jelen törvényt Fiume város és kerületében az ottani viszonyok figyelembevételével rendeleti uton külön léptesse életbe.”207. §. 33 ORDAsi Ágnes: Egy betiltott kisebbségi lap. A fiumei La Difesa története (1898-1901), 76, http://www. prominoritate.hu/folyoiratok/2017/ProMino-1702-04-Ordasi.pdf (letöltés ideje: 2019. 03. 12.), 66. 
Zárszóként arra szeretném biztatni önöket és a tudomány most távol lévő képviselőit, hogy kutatómunkájuk során jussanak bár olyan eredményre, amely a nemzetiségi törvény erényeit emeli ki vagy épp hibáira mutat rá, de egy percig sem feledjék, hogy a korabeli Európában csak kevés helyen törekedtek a nemzetiségi nyelvhasználat ilyen magas szintủ törvényi szabályozására. És ez önmagában is tiszteletre méltó.

\section{Irodalomjegyzék}

1. CsászÁr Ferenc: A fiumei kikötő. II. Füzet, Budán a' M. Kir. Egyetem betủivel MDCCCXLIII.

2. Csizmadia Andor: A magyar városi jog. Reformtörekvések a magyar városi közigazgatásban. Győregyházmegyei Alap Könyvnyomdája, Kolozsvár, 1941.

3. EöTtevÉnyi NAGY Olivér: Fiume és a Magyar Tengermellék. A Tenger, A Magyar Adria Egyesület Közlönye, 1913. január-február.

4. Joó Gyula: A másfélszázados polémia Fiume birtokáért = Emlékkönyv a Kecskeméten müködő Egyetemes Református Jogakadémia fennállásának 100. évfordulójára (1831-1931), Egyetemes Református Jogakadémia Tanári Kara, Kecskemét, 1932.

5. LÁzÁR Gyula: Fiume, a magyar korona gyöngye, Franklin-Társulat, Budapest, 1881.

6. FEST Aladár: Fiume Magyarországhoz való kapcsolásának elözményeiröl és hatásairól, Századok, 1916/4-5.

7. FEST Aladár: Fiume története = Magyarország vármegyéi és városai: Fiume és a magyar-horvát tenger part, szerk. szikLay János, BoRovszky Samu, „Apollo” Irodalmi és Nyomdai Rt. Budapest, é. n.

8. JАKАB Elek: A magyar Fiume, Nyomtatott a Magyar Királyi Egyetemi Könyvnyomdában, Budapest, 1881.

9. Kor Gyula: Az olasz közigazgatás-tudomány müvelöi, és hatásuk a magyar közigazgatás-tudományra (1842-1942), Polgári Szemle, 2014/3-6.

10. NAGY Adrienn: Fiume dualizmus kori oktatásügye és a Magyar Királyi Kiviteli Akadémia, Korall, 2014/56.

11. NAGY Ferenc: Magyar városi jog. A Rendezett Tanácsú Városok Polgármestereinek Országos Egyesülete, Budapest, 1912.

12. ORDASI Ágnes: Dárday Sándor miniszteri tanácsos jelentése a fiumei kormányzati viszonyokról 1897. február 25, Lymbus Magyarságtudományi Forrásközlemények, Budapest, 2018.

13. ORDASI Ágnes: Egybetiltott kisebbségi lap. A fiumei La Difesa története (1898-1901), 76, http://www.prominoritate.hu/folyoiratok/2017/ProMino-1702-04-Ordasi.pdf (letöltés ideje: 2019. 03. 12.)

14. SCHNierer Gyula: Fiume múltja és jelene, Nemzetgazdasági Szemle, 1882/3.

15. S. Pallós Piroska: Támadás Fiume autonómiája ellen. A fiumei közigazgatási bizottság 1897. évről készült jelentése nyomán, Közép-Európai Közlemények. Történészek, geográfusok és regionalisták folyóirata, 2013/3.

16. SzÁNTó Andor, KRÁL Vilmos: Fiume államjogi helyzete, Vas Tivadar Könyvnyomdája, Budapest, 1901. 